\title{
The Training Mode of Improving the Quality of Civil Engineering Professional Teachers
}

\author{
Hongbo LIU', Jing SUN ${ }^{\mathrm{b}}$, Pengfei $\mathrm{LI}^{\mathrm{c}} \&$ Yan HAN ${ }^{\mathrm{d}}$ \\ ${ }^{1}$ Hebei University of Technology, 13 Chaoyangxi Street, Zhangjiakou, Hebei Province 075000 \\ abo-hong@126.com, ${ }^{b}$ kathy2011joy@163.com, ${ }^{c} 365319355 @ q q . c o m,{ }^{d} 78776541 @ q q . c o m$
}

\begin{abstract}
The civil engineering requires that teachers grasp the profound theoretical knowledge and strong practical engineering skills. Only there are good training modes in the university, we can improve the ability of teachers. In this paper, we explored the training mode of civil engineering professional teacher in the construction university. Based on the Hebei University of Architecture, we analyzed the basic requirements for engineers, discussed the ability request of civil engineering professional teacher. Finally, we put forward the training model in the process of training talents for realizing the civil engineering professional training objectives.
\end{abstract}

KEYWORD: Training mode; Civil engineering; Professional teacher

\section{INTRODUCTION}

Teachers are the foundation and the most important resources of colleges and universities. All aspects of the development of colleges and universities were determined by the quality and level of teachers. As we know, the academic activities of colleges and universities, the overall quality of students, the ability to provide service for society directly, the university's ability to access resources from society were affected by the teachers' ability.

The civil engineering requires that teachers grasp the profound theoretical knowledge and strong practical engineering skills. With the time went on, the capacity requirements were also different in different periods for teachers. But their professional skill and practical teaching ability can't meet the need of all kinds of society. So we must find some effective training mode.

There are many scholars have studied the competence quality of teachers in the university. Some have studied the engineering practice ability for the civil engineering professional teachers. Others have carried on the related research about the influence on the professional course and registration system. However, few research have been done on the training mode of civil engineering teachers in the applied architecture university. In this paper, we explore the significance and role of training model of civil engineering professional teachers' quality. Then, the requirement of society for the civil engineering professional teachers was summarized according to the relevant research from many aspects. Finally, some key training models were pointed out based on the Hebei University of Architecture, and many suggestions were put forward.

\section{REQUIREMENT}

With the accelerated process of urbanization in China, the demand for the high quality talents in the civil engineering field will be increasingly for a long period. The development strategy of innovation oriented country and university proposed requirements for teachers, which prompted us to investigate the training model of civil engineering professional teachers.

\subsection{Teaching}

A teacher's most important mission is to teach students. In the process of teaching, teachers are required to highlight the innovation and application. Research on classroom teaching model and practice teaching model[1] is important not only for deepening practice of teaching but also for building theory of teaching.

At present, the quality of the master students' education put forward higher requirements for teachers' team, especially the tutorial must have the ability on research and innovation. Accepted favorable professional training, student should have solid rationale and practice experience, and have better research and analysis ability. 


\subsection{Scientific research}

Scientific research is another important responsibility of the university teachers. University teachers should explore, discover the new phenomena, new research theory, and try to apply to our production and our life. Teachers must have a certain amount of scientific research interest and ability, so they must read a large number of documents and papers, they must learn many scientific research theory and know the reality project. Through research activities, they will know about the development about the subject and master the subject forefront information. After indepth and meticulous research, some achievements in scientific research will be made, which will promote the progress of human society gradually[2].

Because civil engineering is a very strong practical, scientific research cannot be divorced from reality. Scientific research should be derived from the project and serve for the project from the angle of combining the theory with practice. There is no national boundaries in the scientific research, so researchers should also have international vision and understand their discipline in the world situation.

\subsection{Serve the society}

Civil engineering professional teachers should make some training for the people with their professional knowledge and skill. Some technical suggestions for the government should be provided by these experts. After government accepted the professional construction, research can directly service for our society. Civil engineering professional teachers should use professional advantage to carry on the analysis and try to settle down many real complex engineering problem and summarize lots of experience and theory. Civil engineering field is extremely wide, including geotechnical engineering, structural engineering, water supply and drainage engineering, etc. Only we go into the practice closely, the new problem can be found and the theory can be tested.

For teachers, we should provide more opportunities, so that our students will fully contact with reality and get more exercise. Students also increased knowledge, while we were serving the society. Practice is about more than book learning, it also teaches you learn how to think.

\subsection{Others}

As a member of colleges and universities, a teacher also need complete many other job. Except the scientific and technical innovation and relent cultivation, discipline construction, laboratory construction and the improvement of academic staff and faculty members should be done by teachers.
These works are very important, but they are also complicated and meticulous.

\section{MAIN PROBLEMS}

\subsection{The lock of civil engineering practice}

Teachers' time is limited and their ability is limited. To complete so many work successfully need lots of time. Especially, young teachers must spend many time to learn lots of knowledge, so that they can teacher their students, for teaching is the teachers' bounden duty. After class, they must go to library to query literature or go to laboratory to engage a test.

Civil engineering need lots of practice. Teachers also have to learn many practice. Actually, it is well known that our school attached great important to the practice teaching.

However, in our college, many young teachers, and becoming teachers soon after they obtain their masters or doctor's degrees without practical teaching experience, so they are weak in practice, they are incapable of turning the academic knowledge into the education. This condition will lead teachers cannot contact theory with reality, without enough practical engineering experience. It is hard for teachers or students to understand the profound theory without practical civil engineering practice.

\subsection{The lock of the high level of scientific research}

In our college many achievements in scientific research and scientific research award have been acquired. But that was not enough, for few research results stand at the world. We need try to apply for research projects of state funds, and published a large number of high level papers. All the teachers' strength should been concentrated and we should form a joint force. Of course, we have formed the scientific research direction of certain advantage for a long time. We need many leading talents in the scientific research and we should try to declare more scientific research project.

Actually, the high level of scientific research need more condition. The experimental conditions of our school have accumulated many years and owned some high quality instruments used in the teaching and scientific research. More money is needed to put into scientific research equipment in the future. Only through the verification test many theory can be make sure. These devices cannot only be used for teaching, but also can be used for scientific research, even serving the society. Students learned the operation and application of these instruments, which will enhance their professional ability and interest. If student can learn this advanced equipment operation in the school, their practical ability and professional ability will be improved greatly. 


\subsection{The ability of the serve the society}

The ability of the service the society is another important ability for colleges or universities. This ability originated from the accumulation of all advantage resources, for example, information resource, instruments, high-tech talents, and intellectual property rights.

Our school's advantages mainly concentrated in the field of civil engineering. Our team of teachers and students have been actively involved in a lot of engineering project. Through these activities, economic returns and social impact was achieved. It was more important that our school team get exercise and the influence of our school in this field was improved.

However, the ability of the service the society is limited, for the quality and quantity of participation in the project need to be improved in the future. Especially, when Zhangjiakou and Beijing were cooperating to bid for the Olympic Games, we should seize more opportunity to serve our society.

\section{MEASURES}

The society has the very high request for the civil engineering professional teachers, and our team has make some achievements. But for the development of Hebei University of Architecture, there are many problems need to be solved.

These problems are not isolated. These problems are complex and intertwined and the influence factors for these problems are also complex[3].

Based on the Hebei University of Architecture, we have analyzed the basic requirements for engineers, discussed the ability request of civil engineering professional teacher. Now we put forward the training model in the process of training talents for realizing the civil engineering professional training objectives.

\subsection{The renewal of concept}

To improve the quality of the teachers of the civil engineering major is not only the inevitable requirement of the external environment, but also the internal development of individual teachers. Firstly, our college located in Zhangjiakou, which is cooperating Beijing to bid for the Olympic Games. This opportunity is rare. Secondly, it is a huge system engineering that our college will upgrade to university. Therefore, civil engineering professional teachers face many opportunities and challenges. At the same time, these professional teachers must overcome many difficulties.

The renewal of concepts include that we should actively look for development opportunities. The most important task of the teacher is to train talents for the society. We should make full use of the resources around us.

From one hand, young teachers should put into the construction actively like our old teachers. Our old teachers have great experience in engineering, for example: concrete structure, masonry structure, steel structure design and construction, project supervision, engineering testing, engineering budget. We can communicate with them and learn from them day after day.

From another hand, young teachers must break through the research difficulties. Many our teachers are doctors' and masters' graduate tutors. We can work together with them to exchange research thesis, learn how to write paper, learn the instrument operation etc. In this way, we can integrate into a whole team and formed a professional advantage.

Meanwhile, we can seek power and resources from the society. We can combined with a large number of alumni to practice and do some scientific research. We can also go to study in a higher level university or participated in more training and conference communication. We can also find a chance to go abroad for study.

In a world, we must take into account this problem rationally. We should be fully aware of the gap between social requirement for civil engineering professional teachers and the practical problems. Most importantly, we should find strength from the social parties and advance sufficiently in our teaching and scientific research.

\subsection{The school policy}

The school policy is very important for the civil engineering professional teachers, for the school policy usually play an important role in leading and guiding. The development of teachers' professional progress must comply with the policy. The school policy must have a certain advance and should give full consideration for the problem during the development of the school.

For the teaching, the education administration of our school has already made a lot of strict teaching management system. Now, the school require the young teacher under the age of 35 must participate in engineering practice more than one year. When they come back from the engineering practice, teacher must do the report and accept the school inspection. In addition, policy require that graduate design of students must integrate with the real engineering. In a word, our college requires students and teachers must carry out a large number of engineering practice.

For the scientific research, our school has formulated many policies. Policy requires high professional teachers must complete a certain amount of research results every year. If teachers complete multiply, they will be rewarded. Of course, if they cannot complete, they will be punished. In 
addition, the policy began to encourage young teachers to study for a doctorate, when they had worked 5 years for our school. At the same time, our school also caused some teachers with rich experience and high degree teachers. But, it was always lack for senior talent and specialist in scientific research.

For the service for the society, our school has already signed the agreements with many scientific research institutes, university, enterprises and institutions. These departments has carry out many project cooperation jointly. The school also has the architectural design and research institute for the society to provide a large number of engineering design services.

Our school put forward to realize leaping development from college to university. Therefore, more and more policy will be put out to lead the development and direction for the future growth.

\subsection{Creating a high level platform}

Here the high level platform refers to the accumulation in professional strength, including software and hardware.

Our school had passed the national civil engineering assessment and has been qualified to grant the degree of master. Civil engineering has a certain number of provincial key disciplines and key discipline development. Our school also has a number of outstanding experts and teachers, including the national outstanding teachers, outstanding education in Hebei province, the national government allowance winner etc. The school preferred a batch of doctoral and master's tutors. We own a group of excellent courses and developed a batch of excellent teaching books to adapt to the new development of the professional.

Hardware is important too. New offices building and laboratories have been built for the college of civil engineering. All of personnel and equipment have already been in place. The college of civil engineering has investment funds to purchase a lot of experiment and scientific equipment. These equipment is important for our research and teaching, which will give great help for us. The more important thing is that we need study the operation of these devices and make a few development and transformation.

Information resources are another important platform. The library has 712,000 books and 284,400 e-books, 2094 periodicals home and abroad.

At the same time, electronic information database also are massive. You can find whatever you want to do. In addition, we should strengthen the exchange with experts in other universities and institutions.

\subsection{The support of government}

The whole school is owned by the state. Hence, all the teachers and students are working hard for our country. Our college located in Zhangjiakou and have trained tens of thousands of students for our country. These students have made important contribution for the national economy.

Our school has transported a large number of talents for our country. In order to server our country, we need our government provide lots of support for the development of our school. Because there are many things were beyond the teachers' or college' ability. Only government can move it forward.

Now, our school want to build a featured university of architecture in service of architectural industry home and abroad. If the government can give school some policy and funds support, our college may be obtain more reasonable and stable development. Of course, the civil engineering professional teachers will get a huge boost

\section{DISCUSSION AND CONCLUSIONS}

With the vigorous development of the construction industry, the requirement on civil engineering professional teachers tend to be more comprehensive. The school has proposed the aim that we will develop from college to university. Only we enhance the high level of the teachers, all these aims can be achieved.

Facing the gap between the demand and reality, we explore some training mode of improving the quality of civil engineering professional teachers. We proposed some mode, which was the renewal of concept, the school policy, creating a high level platform and the support of government. This model had considered fully the multiple subject, which were students, teachers, college, government and society. If it can be successfully applied, it maybe also be extended to other situations.

\section{REFERENCES}

[1] Congjun Zhang and Lan Zong. "Study on the quality of innovation and applied civil engineering professional teachers", Strait Science, 2013(5), 60-63, (In Chinese)

[2] Junping Zhang, Qicai Yu and Huawei Tong et al, "The teacher quality enhancement and innovation of applied talents training-civil engineering", China University Teaching, 2011(12), 21-23, (In Chinese)

[3] Renjie Qiao and Jincui Yu, "Problems and suggestions on China's higher institutions set in the current", Education Teaching Formula, 2015(1), 190-191, (In Chinese) 